\title{
Brakes and barriers of Corporate Volunteering
}

\author{
Pablo Gómez Santos \\ José Luis Fernández Fernández
}

ABSTRACT: The objective of this research is to study which are the determinants for the participation of employees in Corporate Volunteer actions -hereafter CV- that can become barriers and brakes, and which ones can mean negative consequences for the company. Ignorance of managers for these programs, about which are those brakes and its relevance, may be behind the low participation fees that companies have in their Corporate Volunteering Programs.

For this purpose, we conducted a qualitative empirical study to define a model, based on the motivations and determinants of employee participation in corporate volunteer programs. The methodology that we use in order to advance the understanding of this field is common in the dynamics of so-called Discussion Groups or Focus Group (FG). We believe that this methodological approach fits well with the research question and objectives that guide us in this work, since it will allow the reconstruction of real social situations and to capture the interaction between different discourses.

We trust the fact the model proposed really allows advance in knowledge of Corporate Volunteer field, as literature suggested, and we offer a conceptual framework to managers in order to develop CV programs that allows mitigating potential risks and increasing employee participation effectively.

KEYWORDS: Corporate-sponsored volunteerism, employee volunteering, corporate volunteering.

ECONLIT CODES: M14, D64, L31.

How to cite this article: GÓMEZ, P. \& FERNÁNDEZ, J.L. (2017): "Brakes and barriers of Corporate Volunteering", CIRIEC-España, Revista de Economía Pública, Social y Cooperativa, 90, 253-290.

Correspondence: Pablo Gómez Santos, máster RSC y Sostenibilidad, y Dr. José Luis Fernández Fernández, director de la Cátedra de Ética Económica y Empresarial. C/ Alberto Aguilera, 23 - 28015 Madrid. Universidad Pontificia de Comillas. Icade. E-mails: pablogs@ hotmail.com; jlfernandez@icade.comillas.edu. 


\section{RESUMEN}

\section{Barreras y Frenos al Voluntariado Corporativo}

\section{Objetivos}

El Voluntariado Corporativo (VC) es un fenómeno en desarrollo con el que pueden ganar la empresa, los empleados y la sociedad. Esta circunstancia choca con que las cuotas de participación de los empleados en este tipo de programas son realmente bajas. Esto se debe a que los motivos de la corporate philanthropy no han sido comprendidos completamente. Sobre todo, falta investigación en lo referido a los determinantes del VC. Sin aclarar este extremo, no resultará fácil conseguir que aumente la ratio de voluntarios. En definitiva, se aprecia que, si bien los programas de VC crecen en importancia, la investigación empírica es todavía muy escasa y poco conocida.

Así, nuestra investigación persigue conocer cómo opera la voluntad de cooperar en el VC con ánimo de incrementarlo, o lo que es lo mismo, cómo podemos incrementar la participación de los empleados en los programas de VC. Para esto necesitamos conocer: cuáles son los factores determinantes y las motivaciones de los empleados para participar en el VC, y cuáles son las barreras y frenos que impiden o dificultan dicha participación. Nuestra investigación pone el foco en el segundo punto -frenos y barreras- lo que menos se conoce, y para lo que necesitamos estudiar tanto a los participantes en VC como a aquellos otros que no participan en actividades de VC.

\section{Diseño, metodología y aproximación}

Esta investigación persigue obtener la comprensión holística del problema desde un abordaje cualitativo empleando el método de Grupos de Discusión (GD), ampliamente utilizado en ciencias sociales, porque genera diversidad y diferencia; porque permite estudiar actitudes, opiniones y prácticas de los sujetos en los contextos - los empleados en el Voluntariado Corporativo-, y así profundizar en el conocimiento de las barreras y frenos que pueden tener los empleados a la hora de participar en este tipo de programas.

Intentando seguir criterios de paridad y representatividad, los participantes fueron tomados de cinco empresas de sectores y tamaños variados ubicadas en España; que tienen implantado un programa de Voluntariado Corporativo en la actualidad y a las que teníamos acceso. Realizamos seis Grupos de Discusión compuestos por cinco empleados cada uno, tanto participantes habituales en VC como aquellos que no participan. Los criterios de selección pertinentes para responder a la pregunta de investigación y para alcanzar la validez y la fiabilidad cualitativa fueron: la edad, el género, el departamento, la antigüedad en la compañía, el sector empresarial, el tipo de contrato y el tamaño de la empresa. Tratamos de que los grupos fueran heterogéneos con el fin de obtener una mayor 
amplitud, distensión, variedad, obligación de precisar, consenso, información, riqueza, creatividad e innovación. En relación al proceso de codificación, perseguimos principalmente identificar las motivaciones y las barreras que se repetían, y eran comunes a varios participantes. También tratamos de determinar el rango y la diversidad de las concepciones recogidas; así como las opiniones más repetidas aunque fueran expresadas por los participantes empleando distintos términos o en diferentes estilos.

\section{Resultados}

Obtuvimos un ranking de los diversos frenos y barreras, explicamos cuáles son los más importantes y por qué; y analizamos la relación existente entre ellos. Así, veintiocho posibles frenos y barreras a la participación de los empleados fueron detectados en la investigación. El criterio seguido fue el grado de dificultad de superación a la participación que suponía cada freno y barrera. De esta manera, obtuvimos cuatro grupos: 1) Muy alta dificultad de superación; 2) Alta dificultad de superación; 3) Moderada dificultad de superación; 4) Baja dificultad de superación. A su vez, agrupamos los dos primeros grupos bajo la categoría de barreras; y los dos últimos grupos, bajo la de frenos -por el menor impedimento que suponen.

Los participantes de nuestro estudio coinciden con la literatura en que la principal barrera es la falta de tiempo. La barrera tiempo se relaciona con otras barreras, como la disposición de recursos escasos, la no consideración de las motivaciones y necesidades funcionales de los empleados o la ausencia de apoyo managerial. Nuestra investigación aporta en relación a la barrera tiempo, la idea de que, aunque el empleador conceda horas de trabajo para que el trabajador participe en estos programas, el empleado puede considerar esto como una falacia debido a la circunstancia de que, cuando participa en actividades de VC, al regresar debe ampliar su horario para recuperar el trabajo no realizado; con lo que decidir no participar. La segunda barrera más importante que recoge el GD es la carencia de apoyo managerial. En este punto, destacamos la diferencia apreciada entre los papeles que juegan el CEO y los managers. En este sentido y en contra de la idea de diversos autores, defendemos la idea de que el aumento de carga de trabajo ocasionado por la ausencia de un trabajador que se encuentre en una actividad de VC puede generar malestar entre el resto de sus compañeros. Habida cuenta de esta divergencia, consideramos que podría ser necesaria una mayor investigación al respecto. Adicionalmente, identificamos también algunas relaciones entre barreras que se pueden producir dentro de cada grupo.

\section{Limitaciones a la investigación / implicaciones}

Refiriéndonos ahora a las limitaciones del estudio, el número de participantes -treinta- que forman nuestra investigación podía interpretarse como una limitación del mismo. Aunque en relación al alcance de nuestro estudio, cabe insistir en que nuestro objetivo era presentar un marco conceptual sobre las posibles barreras y frenos a la participación de los trabajadores en el VC. Se trata de un estudio cualitativo, de carácter exploratorio, que busca la significación social que estos frenos y barreras pue- 
den suponer para los empleados. Ha quedado, pues, al margen de nuestro objetivo la búsqueda de representatividad estadística, geográfica, sectorial, o de otro tipo. Probablemente, por esta razón merecería la pena realizar una aportación metodológica de tipo cuantitativo con el fin de estudiar si hay diferencias en función de la complejidad de las empresas objeto de estudio con relación a las nuestras.

\section{Conclusiones prácticas / valor original}

Esta investigación explica cuáles son los factores claves del VC y las barreras más habituales en otras actividades de voluntariado; además, señala las razones por las que la falta de apoyo managerial es una de las barreras más importantes en este campo; y finalmente identifica cuáles son las barreras a las participación de los empleados en el VC que difieren o son distintas de las barreras a la participación de los empleados en otros proyectos corporativos.

Al participar en una actividad voluntaria, una persona puede tener múltiples razones que pueden afectar a su decisión. Adicionalmente, el deseo de ayudar a los otros prevalece menos en el VC que en otras formas de voluntariado privado. En relación al voluntariado privado, la principal barrera para que voluntarios decidan no permanecer en la Ong a largo plazo es que se sientan muy controlados o presionados. Igualmente, los factores clave que diferencian el VC del voluntariado público son la intermediación del empleador entre empleado y comunidad y ciertas actitudes hacia al empleador tales como la motivación de impresionar a los managers o ser un buen miembro de la empresa-. Entrando en más detalle, la falta de apoyo managerial es una de las principales barreras de la participación de los empleados en el VC debido a que impide la implementación transversal del proyecto para que llegue a todos los empleados de la compañía. Para alcanzar una mayor participación, primero es preciso que la figura del CEO impulse y apoye el programa de VC, y después que los managers faciliten dicha participación. Igualmente, las barreras a la participación en el VC pueden ser comunes -aunque con sus propias particularidades y posiblemente suponiendo distintos niveles de dificultad de superación- a las barreras a la participación del empleado en otros proyectos de la empresa; salvo con algunas excepciones derivadas del mismo concepto de VC.

Nuestros resultados llevan a la conclusión de que la empresa debe potenciar o alinear su estrategia de VC con aquellas motivaciones y factores que son determinantes para la participación de los empleados; y debe ser capaz de minorar los frenos y barreras que imposibilitan dicha participación. De esta manera, el modelo propuesto permite avanzar en el conocimiento del campo del voluntariado corporativo tal y como era requerido en la literatura; a la par, ofrece a los responsables de las empresas un marco para poder implementar los programas de voluntariado mitigando posibles riesgos, e incrementando de forma efectiva la participación de los empleados.

PALABRAS CLAVE: Voluntariado corporativo, voluntariado patrocinado por la empresa. 


\section{1.- Introduction}

According to Ellen et al (2006) general public and consumer tend to believe that firm behavior can adapt to one of two possible orientations: 1) selfish or strategic approach; and 2) altruistic perspective or oriented to values. This second approach would go beyond the strictly economic, trying to meet the legitimate demands of a wider range of stakeholders: Stakeholder Approach. In line with the first view, there are different positions that oppose company must serve any responsibility that goes beyond the strictly economic. Therefore, they deny the existence of an alleged social responsibility of the company. Thus, some consider that the fact that the company is obligated to solve social issues, apart from being a misconception, is an unfeasible claim (Karnani, 2010); or from a more normative approach, some critics claim that this sort of corporate philanthropy can even avoid companies to achieve their main objective, which is no more than the shareholders maximization profit (Friedman, 1970). The discussion in this regard seems in favor of the second route, i.e., the way to understand company and management from a wider range of what company means; and the achievement of its long-term goals may require strategic connection with the social environment in which it operates (Porter and Kramer, 2002). In this regard, it is being said for more than two decades that the company would have to achieve a triple bottom -Triple Bottom Line or TBL-; and therefore should properly manage not only financial capital but also the ecological and social capital which it handles (Carroll, 1998). From the beginning of these aspects, social capital has been defined as the existing goodwill between groups or individuals and has traditionally been investigated in relation to the capacity of cooperation between societies. Indeed, several forms of CV are connected with some of the most obvious dimensions of the so-called social capital: network, trust and cooperation rules. Moreover, it has been argued that social relationships and resources that strengthen the generation of social capital serve as an opportunity, motivation and ability to unite the players and increase their capacity for cooperation (Muthuri et al, 2009).

Community Corporate Involvement (CCl) appears to conveniently manage social capital, which can take the following forms: 1) Corporate Citizenship; 2) Partnership between businesses and non-profit organization; 3) Sponsorship; 4) Marketing with Cause (Seitanidi and Ryan, 2007). CCl, meanwhile, has been systematically being addressed from a variety of academic and scientific perspectives, such have been, for example, studies connected with business ethics, marketing management, and even competitive strategy (Ricks and Peters, 2013). It should also make a taxonomic approach to $\mathrm{CCl}$, as proposed by Garriga and Mele (2004) to categorize studies related to CSR: Strategic Philanthropy (Instrumental Theory); Corporate Citizenship (Political Theory); Corporate Social Performance (Integrative Theory); Stakeholder Theory and regulations as Ethical Theory (Vaidyanathan, 2008). Within the $\mathrm{CCl}$, the orientation aligned with the approach of Corporate Citizenship would involve an explicit option to return to society part of the benefit that the company has received; this is becoming 
a good neighbor and a responsible member of the community. Naturally, this kind of approach can carry the involvement of employees in CV (Pajo and Lee, 2011). It can also be interpreted as collaboration from the company with the third sector to solve social problems which often escape the government attention; and therefore contribute from the public-private partnership to shaping a better society. As noted, by acting in this way, company would come to behave as a good citizen would, but in this case the agent would not be a person but a company -a corporate agent (Herzig, 2006).

Looking back to consumer attention, it is clear that nowadays, those have much more information on companies social behavior. Mechanisms such as companies websites, blogs, social networks and communication contribute to it. Therefore, CSR activities communicated properly, can make customer has a positive image of the company and, this has the intangible value that means acquiring a good reputation (Groza et al, 2011). But, we must neither forget a key stakeholder, as employees are. It has been noted that there is some correlation between CSR and Organizational Citizenship Behavior (OCB) just because employees -as internal stakeholders- also create demand for CSR, which the company can respond in various ways. One, for example, could be the development of a CV program for employees to get involved in the community. Moreover, it is noteworthy that company philanthropy can take a strategic nature. It will be so, when social action looks to improve the competitive environment of the industry as a whole. In others words, when focusing on the most important contextual conditions in the sector, looking for approaches and practices that enhance resources and capabilities that the creation of sustained and greater value depends on. In this sense, Porter and Kramer (2002) said that, if the philanthropy was strategic and was geared to the general objectives of the company, it probably would also generate tangible benefits for the company. It is therefore necessary that this strategic philanthropy, in order to be effective, has to be implemented and managed with the same professionalism that serves the core business (Bruch and Walter, 2005). Financial Corporate Philanthropy (FCP), meanwhile, involves donations, both financial, and time employees, goods or services. Naturally, the social impact of these practices also generates reputation and image. This being so, it is extremely important that the company chooses strategic partners with whom to deploy CV policies and practices. It should try to get the impact to be quantifiable and that consequences were significant (Block et al, 2015).

As we can see, it is within this framework of philanthropy and corporate citizenship, where this phenomenon of CV is better located. These CV programs originated in the US in 1970's (Sajardo and Serra, 2008); since the 1990s are widespread in UK companies; and they are currently being developed with more strengthen in the Continental Europe companies, especially in Holland, Switzerland and Germany (Herzig, 2006). To give minimal information, we would say that more than $90 \%$ of Fortune 500 companies support such corporate volunteer activities (Boccalandro, 2009). On the other hand, literature of the last decades (Kim, and Kim, 2014) has identified the trend of rapid growth of such programs as a way to answer the growing expectations of CSR practices. It has come to see that companies can make a difference in the communities where they operate (Grant, 2007) when they are able to organize and put together the convenient means for their employees to become involved in $\mathrm{CV}$ (Sajardo and Serra, 2008; Knox, 2015). 
Volunteering belongs to the group of so-called helping behaviors and involves a commitment of time and effort (Wilson, 2000) without coercion or remuneration (Millette and Gagné, 2008). In this way, CV differs from public volunteering by brokerage employer between employee and community, and by the attitudes towards the employer (Jones, 2010) as motivation to impress managers (Grant and Mager, 2009), or being a good member of the company (Peloza and Hassay, 2006). In short, it can be said that CV is a prominent feature that is growing in community involment programs (Muthuri et al, 2009), which allows the company to make a tangible contribution to the community and involve their employees (Sajardo y Ribas, 2014; Lee and Higgins, 2001). It is a tool to promote the CSR aspects that most directly have to do with social action of the company. As we said, it is a way that allows the company to act as a good corporate citizen (Pajo and Lee, 2011); and represents an innovative business strategy (Bartsch, 2012), especially for multinationals operating in a global environment and are fighting for greater demand for their products, increase social commitment; and strengthen the legitimacy of the company in the market (Lee and Higgins, 2001).

Although there are approaches to CV that highlight the interest of the company to obtain a future benefits through such programs (Ven van de and Graafland, 2006), literature -especially the one which is approached from the perspective of Exchange Social Theory- abounds on the idea that companies develop CV programs to generate a win-win situation where they benefit too, in combination with the environment and society as a whole (Caligiuri et al, 2013; Pavlova and Silbereisen, 2014). CV, moreover, seems to be a powerful tool not only for attracting and retaining talent, but also a stimulus for an increased productivity. All together it seem like, companies that have happy and engaged employees are more productive and beneficial (Bartsch, 2012). In this sense, Tuffrey (2003) -who collects the work of Aon (2000)- emphasizes the idea that replacing an employee who leaves the company, costs half annual salary of a worker. If we wanted to classify synthetically the types of benefits or motivations that encourage the company to implement a CV program we could say like Aguilera et al. (2005) which mainly confined to the three next lines: instrumentals, relational and moral.

In short, according to what we are saying, companies that choose to implement CV are motivated to get -some or all- of the next benefits: reputation and image (Peloza and Hassay, 2006; Jones, 2010 ; Block et al, 2015; Lorenz et al, 2011; Herzig, 2006); legitimacy (Pajo and Lee, 2011; Lee and Higgins, 2001); external expectations (Lorenz et al, 2011), social responsibility and competitiveness (Lorenz et al, 2011; Aguinis y Glavas, 2012); productivity (Geroy, et al, 2000); consumer loyalty (Plewa et al, 2015; Jain et al, 2012; Herzig, 2006); sales (Lorenz et al, 2011; Herzig, 2006); team work (Lorenz et al, 2011; Lee and Higgins, 2001; Jones, 2016); talent and recruitment (Zappalá, 2004; Greening and Turban, 2000; Jones et al, 2014); low cost training (Caudron, 1994); and commitment/worker skills (Herzig, 2006); pride of belonging (Lee and Higgins, 2001). Moreover, CV can influence the objectives of Human Resource management in four ways, and thus benefit employees: 1) time provided for the development of CV allows a better work and personal life balance; 2) supporting employees with matched initiatives allows employees to develop initiative and values; 3 ) team and fundraising events allow better internal cohesion of workers; and 4) involvement in CV community enables the development of skills of employees (Tuffrey, 2003). 
Summing up so far, we have contextualized CV field, seeing how it connects with other areas such as philanthropy, social capital and corporate social responsibility; and we have seen that it is a developing phenomenon with which company, employees and society can win. This circumstance collides with the fact that employee participation quotas are low (CECP, 2015). This is because the corporate philanthropy reasons have not been covered comprehensively (Ricks and Peters, 2013). Above all, there is lack of research in regards to the determinants and barriers of CV (Grant, 2012), and without clarifying this, it will not be easy to increase the number of volunteers (Brudney and Gazney, 2006). Definitely, it is widely believed that while CV programs grow in importance, empirical research is very little and remains unknown.

Then, our research question consist on know how the will to cooperate in CV works with the intention of increasing it, or what is the same, how can we increase employee participation in CV programs. For this, we need to know: 1) which are the determinants and motivations of employees to participate in $\mathrm{CV}$; 2) what are the barriers and obstacles that impede or hinder such participation. Our research focuses on the second point - brakes and barriers - which are least known. For this purpose we need to study the participants and those who do not participate in CV actions as well. We will do this from a qualitative approach using the Focus Groups method, widely used in social sciences, because it creates diversity and difference; because it allows us to study attitudes, opinions and practices of subjects -employee- in contexts -Corporate Volunteering-, and thus to deepen in the understanding of the barriers and brakes that employees can suffer to participate in $\mathrm{CV}$. -Ours is an exploratory study that does not seek reach statistical, sectoral, geographical or other kind of representation, but achieve a social significance.

\section{2.- Conceptual Framework}

We understand that in order to get to know the barriers to employee participation in CV, it is necessary previously that employers know: institutional factors, individual factors of their employees - sociological, psychological and religious - as well as the determining factors and employees motivations to participate in CV. Let us see next, part of what literature collects about it. 


\section{Figure 1. CV Conceptual Mark: Drivers and Barriers to employee participation in CV}

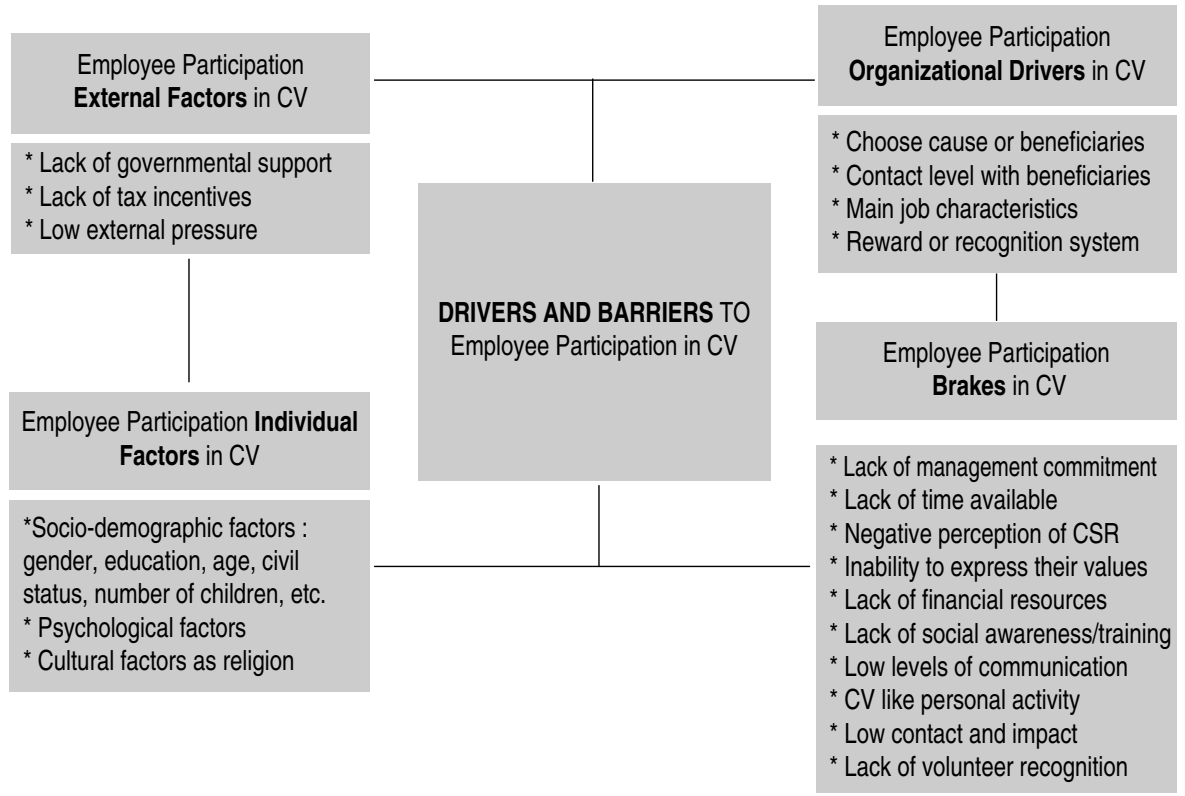

SOURCE: Prepared by authors.

Institutional factors. As noted above, it has been pointed out that from a macro point of view that 1) human capital -education, income, and health-, 2) social capital -number of children, informal interaction, etc.- (Musick et al, 2000) and 3) cultural capital -such as religiosity- (Wilson and Musick, 1997) are positively related to corporate volunteering. In fact, in those countries without the adequate infrastructure to volunteer, though there are people who have high motivation to respect a low turnout usually occurs (Plagnol and Happert, 2010). In line with what we have just stated -and at least according to the literature of the Anglo-Saxon area- it insists that good predictive indicators of participation in CV have to do with, among others, the following ones: the presence of a tradition and humanist culture, the existence of regulations, standards or competitions, and awards evaluated by third parties. All this, of course, considering context and social climate of the country; socio-cultural environment (Aguinis and Glavas, 2012) and pressure exerted by social groups (Kim and Kim, 2014). Obviously, political, recreational, social and media participation, also affects the way people are involved in CV programs (Smith, 1994).

Individual factors: socio-demographic. Primarily, also in Anglo-Saxon countries, it could be stated as follows: those children who volunteer in their stage of High School develop prosocial attitudes that make it more likely to continue practicing volunteering in the stage of College too, and extend this prac- 
tice of adults (Astin, 1993 cited by Wilson, 2000). Similarly, young people who practice volunteering are less likely to have problems in the future as truancy and drug use (Wilson, 2000). In relation to the cycle of an employee's career, the Individual Agency suggests that high levels of engagement and job uncertainty can lead to a greater willingness to volunteer of young employees (Pavlova and Silbereisen, 2014). Thus, some authors as Catalano et al (2004) defend the thesis that volunteering can be given more frequently in those middle-aged workers with part-time contracts with small children. There is also a positive relationship between $\mathrm{CV}$ and mental health of employees participating in these programs. Thus, older adults who do volunteer work may have greater life satisfaction, less depression and anxiety (Konrath, 2014); and a better perception of their own health (Van Willigen, 2000). Also emphasizes that physical demand that involves the practice of volunteering can be a hindrance for the elderly (Li and Ferraro, 2005). But on the other hand, it can also have a positive impact on the health of the volunteer because of the development of their own physical activity, as it can reduce the cognitive impairment of the person and their levels of depression (Luoh and Herzog, 2002).

Individual factors: psychological. Volunteering can occur when people changes their own concept. For example, as a result of situations as a serious challenge in life like death, injury or chronic physical illnesses (Konrath, 2014). In this regard, it noted that the exercise of volunteering can have a positive impact on the worker, such as improvements in life-satisfaction, in self-esteem, or in selfrated health. It can lead to improvements in the type of occupation, in increasing education and functional skills; and even, in increasing life expectancy (Wilson, 2000). Another psychological factor to consider in $\mathrm{CV}$ is empathy because generosity and orientation toward others are more common in people who have a high level of empathy. This would lead them to engage in $\mathrm{CV}$ and thereby to obtain an improvement in their psychological well-being (Konrath, 2014). Thus, as noted by Ryan and Deci (2001), CV can relate positively in terms of welfare, fulfillment, and sense of meaning or purpose of life (Konrath, 2014). These authors, moreover, distinguish between the 1) hedonic approach, which focuses on happiness -understood in a weak sense, as fun and satisfaction- as a generator of pleasure and pain reliever; and 2) eudaimonic approach, which focuses on the strong concept of happiness -eudaimonic of classical philosophy and points to the meaning and self-realization-. From this perspective, welfare is related with the degree in which the individual is fully functioning (Ryan and Deci, 2001; Grant, 2007).

Individual factors: religion. As noted by recent research (Konrath, 2014), religiosity does not seem to be a determining factor in order to engage people in CV practices. Although most religious beliefs are associated with the spiritual welfare and encourage their faithful to care for the poor and needy, religious motivation -as has already been pointed out more than two decades ago- it does not make that most religious people dedicate more time volunteering than those who are not (Cnaan et al, 1993). However, it is said that it is possible to find significant differences between different ideological and religious orientations. For example, conservative religious people see volunteering in terms of sacrifice; while liberals religious tend to consider it in terms of self-improvement (Wilson, 2000). In the case of Catholic, the relationship between Church involvement and volunteering is established at an early age, and maintains its intensity over the years. Meanwhile, among liberal Protestants con- 
nection is established at middle age; while conservative Protestants who attend church regularly are less likely to be involved in a secular voluntary; although it is more likely to be involved in volunteering linked to their Church (Wilson and Janoski, 1995). Meanwhile from Buddhist perspective CV is an activity of citizenship based on achieving higher levels of welfare and wisdom, which are acquired by practicing compassion and cooperation with others (Prayukvong and Rees, 2010).

Employee motivations: satisfaction of personal aspirations. The reasons for employees to participate in CV can be multiple and they may concern with the desire to satisfy personal aspirations, of varied types and functions. For example, literature has indicated that personal needs are related with: values (altruism), understanding (learning experiences), social experiences, carreer (skills professional), protection (ego and guilty for being luckier), enhacement, and self-esteem (Clary et all, 1998). In parallel to achieving those objectives, certain skills are usually developing (Thoits and Hewitt, 2001; Geroy, et al, 2000; Lee and Higgins, 2001), such as improving communication skills -speaking public or presentations- leadership, mentorship, projects management, ability to motivate others and provide feedback, teamwork and time management (Jones, 2016). Literature indicates many other motivations to explain that employees participate in CV. These include the following: promotion and career development (Thoits and Hewitt, 2001; Lee and Higgins, 2001); expression of own values (Pajo and Lee, 2011); obtaining meaning and purpose; being able to assess what you have; possibility of opening a break at work or in life itself (Geroy et al, 2000); feeling good, have fun, do something different, change roles, helping a specific group, teamwork (Lee and Higgins, 2001); and get contacts that can serve at work, and see others life (Geroy, et al, 2000).

Reasons related to Organizational Citizenship Behavior (OCB) and Impression Managers (IM). OCB term was conceived by Bateman and Orgam (1983) and is known as well, as extra-role or prosocial behavior (Barkay, 2012). It is a personal and voluntary behavior that is not reflected in the official payment system of the company (Bozkurt and Bal, 2012). We start from the idea that companies may need employees to perform tasks beyond those expressly referred to in the definition of their job. Rioux and Penner (2001) collected three fundamental reasons related to OCB: 1) pro-social values -wanting to connect and help others-; 2) organizational reasons for concern -employees wants to help and be involved in the organization-; and 3) Impression Management reasons -employees desire to be viewed positively by their superiors-. Prosocial motives -people oriented- tend to predict greater involvement of coworkers. According to them, the reasons for organizational concern refer to the organization to improve policies and procedures (Kim et al, 2013). However, as Rioux and Penner (2001) noted, IM motivations maintain a weaker relationship with OCB. CB behaviors based primarily on IM pervert a social positive quality to incorporate other less desirable qualities, such as opportunistic reasons, attempts at deception, and other counterproductive behaviors. We can thus distinguish the figures of the so-called "good soldiers" and the "good actors" taking into account these two criterias: the inconsistency of deliberate behavior, and allened false pretense as a discrepancy between the claims and present deeds (Snell and Wong, 2007). Employees who are both "good soldiers" and "good actors" are more likely to show themselves as good citizens too (Grant and Mayer, 2009). 
Motivations arising from job satisfaction, autonomy and Self-Determination Theory (SDT). The significance or task impact is a determinant of CV (Grant, 2012). The socio-relational design of work can motivates employees to worry about trying to "make a difference" in others. It is due to, the employees use to evaluate: beliefs, emotions, behaviors, group membership and the value they provided to beneficiaries of voluntary action (Grant, 2007). For its part, the Job Characteristics Model (JMC) can be applied to the context of the volunteers because the job design can enhance autonomous motivation of volunteers, satisfaction, in-role performance and retention. Autonomous motivation stands as mediator between job characteristics and job satisfaction (Millette, and Gagné, 2008). According to Ryan and Deci (2000), Self-Determination Theory specifies the drivers of selfdetermined motivation to a task, in reference to human learning, interpersonal relationships, and people management and social environments (Opoku- Dakwa, 2017). In this sense, motivation can be a) intrinsic -with more autonomy features - or b) extrinsic (Millette, and Gagné, 2008). Meanwhile, those specific to the task that cause a greater sense of autonomy of the worker make also increase employee intrinsic motivation to participate in CV (Pajo and Lee, 2011). In the same way, individual differences - causality orientations - are moderators of the relationship between autonomy supportive leadership and autonomous or controlled volunteer motivation. Thus, volunteers with control orientation may have difficulty setting limits, and if supervisors refuse to allow them to perform additional tasks (Oostlander et al, 2014).

Barriers. The acceptance of CV by the employee as CSR activity is complex. We must consider, therefore, the different possible levels of acceptance, identification and development (Rodrigo and Arenas, 2008). We start from the fact that lack of government practices that legitimize, finance, and facilitate volunteer organization can undermine the level of volunteer involvement in the community (Haddad, 2004). In the same way, it should be noted how periods of economic crisis have not left much time for people to volunteer. Then, in an economic recession context, CV has tended to be seen as superfluous, dispensable, and away from the core business (Plagnol and Huppert, 2010). Leaving aside these more macroeconomic variables, literature show that time is the main barrier to employee involves in CV (Geroy, et al, 2000). Likewise, the fact that managers are not sufficiently aligned with CV project can be a brake itself (Peloza and Hassay, 2006).

In relation to the employee perception of company CSR and its objectives, if the employee perceives company CSR in a negative way their involvement in CV projects will be more difficult to achieve because there is a positive relationship between those perceptions regarding CSR and its involvement with the company (Glavas, 2016). Then, literature also states that employees perceptions about company supporting a CV just with imagen purposes, makes they have less emotional committed to the program in question (Gatignon-Turnau and Mignonac, 2015). In this sense, we see that the exclusivity of instrumental motives may damage the relationship between company and employee (Henning and Jones, 2013) and can make employees perceive it with suspicion (Pajo and Lee, 2011). This situation can enhance skepticism among workers, who feel that company has no integrity and acts by hidden motivations. On the other hand, it must take into account that the employees who interpret $\mathrm{CV}$ as a private activity often oppose the company to develop this type of programs (Van Der Voort 
et al, 2009). Obviously it will be also difficult to count on all those do not have the will to help the community and collaborate with it (Lee and Higgins, 2001). In the same way, the fact that a worker does not feel happy can make it less likely to help others. Moreover, some studies consider the relationship between volunteering and happiness is bidirectional (Konrath, 2014) because Volunteering increase welfare and happiness; and reduces the negative perception of problems.

Focusing on those employees who have the will to help the community, it often turns out that it is not they who take the initiative (Bowman, 2004). This is usually because they do not know the relevant information on the social context in which CV could take effect. This, moreover, should be taken into account by those seeking to recruit employees for $\mathrm{CV}$ activities. Then a non-effective communication will be in impediment to achieve participation. Moreover, sometimes the internal communication about this type of programs is not based on a precise use of language and does not consider the understanding of employees motivations. It is precis to take into account and use an accurate language to build trust and improve the relationship (Seitanidi and Ryan, 2007). Connecting with motivations, design activities that are boring or not interesting for workers, can be another barrier because $\mathrm{CV}$ is seen by employees as an enjoyable free time activity that generates satisfaction; an opportunity to express their personal values and contact with others (Lorenz et al, 2011). The same can happen if a worker participating in $\mathrm{CV}$ sees that it does not satisfy their functional needs, such as if they do not see improvement in their career, or a development of new skills.

In relation to the project, lack of provision of economic and material resources can be an obstacle as well if the employee does not realize this support materialized in some ways, such as pay slips, cash donations, company equipment's to different projects, or company payment for maintenance and transportation costs (Pavlova and Silbereisen, 2014). Also, lack of support to voluntary employee who behaves like a "good soldier" when developing its work as an ambassador of the company in the community -not making available shirts, hats or other garments with the company logo- can be another brake to participation (De Gilder et al, 2005). In relation of available resources, if the volunteer employee does not have a previous personalized CV training and adapted to its peculiarities it is more complex to reach a greater participation (Lee and Higgins, 2001; Rodell, 2013) because of the fear, lack of knowledge or the impossibility that the voluntary experience be satisfactory and invite to repeat.

The literature also collects other possible barriers in relation to impact, contact and peer participation of voluntary activity. From the point of view of the impact of voluntary activity, employees perception that their activity implies a low or zero impact on the beneficiaries may also impair their participation. This is because the perception of high-impact activities in the beneficiaries increases prosocial worker motivation and makes a difference. Employees can give great importance to the level of contact with the beneficiaries of CV activities. Their participation can be reduced if the company organizes CV activities that do not allow interacting with the beneficiaries in terms of physical proximity, depth and frequency enough (Grant, 2007). At this point, also note that coworkers participation can have a negative effect on CV (Peloza et al, 2009). 
Finally, in relation to the recognition of voluntary activity, we emphasize that moral identity can have two dimensions: 1) internalization: moral traits that are self-centered; and 2) symbolization: moral traits that are reflected in external responses. In this sense, recognition can increase participation in CV among those workers with high moral identity symbolization and low moral identity internalization (Winterich et al, 2013). The reward system may be part of the corporate strategy, and can be articulated in several ways, such as a specific donation for every hour of employee volunteering. In this way, lack of a system of rewards can also reduce participation. Thus, these systems can be part of the corporate strategy, taking various forms such as a certain donation by each hour of employee volunteering (Geroy, et al, 2000).

\section{3.- Empirical Study and Results}

As we discussed, we believe that for the holistic understanding of the problem Focus Group method is suitable because it allows us to capture the interaction of the various speeches of employees, reconstruct the situation of $\mathrm{CV}$ and study attitudes, opinions and practices of employees in the context of volunteerism. Krueger, understood Focus Group as "a carefully planned conversation, designed to obtain information from a defined area of interest, in and nondirective and permissive environment" and "that does not pursue inference but understanding; we do not want to abstract general data of the whole population, but to descend to the whole panopia of particular opinions coexisting in it; we do not make statements about a population, but we perceive how its members perceive a situation" (Krueger, 1991: 24:100).

Trying to follow a parity and representation criteria, participant were taken from five companies of different sizes and sectors located in Spain that have implemented a Corporate Volunteer Programs nowadays, and we have access to. We arranged six Discussion Groups, of five employees each one, regular participants in $\mathrm{CV}$ and not. Three men and three women of different ages were selected from different departments of each company. In addition to age, gender, and the employee department or work area (Human Resources, Administration, Marketing, Finance, Production and Commercial); the selection criteria for responding to the research question and for achieving qualitative validity and reliability were: years of seniority in the company, business sector (finance, services, marketing, technology and internet), type of contract (indefinite and temporary) and size of company (SMEs and large companies). With the thirty employees selected, as we have said, we formed six groups of five members each. We try the groups to be heterogeneous in order to obtain a greater amplitude, strain, variety, obligation to specify, consensus, information, wealth, creativity and innovation.

The focus groups lasted no more than one hour, and were recorded, and were transcribed later accurately in separate Word documents in order to be rigorously analysed. Participants expressly agreed to be recorded and expressed their consent in order for the data obtained to be used in our 
research; preserving, in any case, anonymity. In relation to the codification process, we mainly sought to identify the motivations and barriers that were repeated, and were common to several participants. We also tried to determine the range and diversity of conceptions collected; as well as the most repeated opinions even if they were expressed by the participants using different terms or styles. Additionally, after a first general reading of transcripts, an investigator performed an initial (deductive) identification of codes and categories, based on key barrier found in the literature, while another investigator performed a free (inductive) coding not related to previously categories defined. After analysing the different proposals, the research team reached consensus on the criteria on thematic barriers of interest and the codification guidelines. In addition, taking into account Peloza and Hassay (2006) we followed the same theoretical data analysis approach of Glaser and Strauss (1967) used by them, which assumes that data obtained and theory are compared and contrasted in a reiterative way .

Analysing the data obtained from the FG, we found 28 possible brakes that can hinder or discourage employee involvement in $\mathrm{CV}$, as recorded on Figure 2. The consequences originated by these barriers that the company could suffer without developing strategies to eliminate or mitigate them, also surfaced.

\section{Figure 2. Possible barriers and brakes on employee participation in Corporate Volunteering Programs}

\section{POSSIBLE BARRIERS AND BRAKES ON PARTICIPATION}

* Lack of government support and tax incentives

* Low external pressure on the organization

* Low levels of satisfaction /employee involvement

* Insufficient workers identification with the company

* Disregarding the possible contextual variables

* Lack of management commitment: CEOs / managers

* Lack of support to "good soldiers" and "good actors"

* Sense of obligation or pressure to participate

* Inability to express employee values

* Lack of social awareness / internal training

* Negative perception of CSR by the employee

* CV perception as PPRR/employee skepticism

* Program designed and organized incorrectly

* Prior poor personal experience in CV activities
* Lack of financial resources and material resources

* Lack of available time to participate in CV

* Not consider employees motivation

* Program does not meet functional needs

* Little contact with beneficiaries of the program

* Reduced impact of voluntary activities

* High company staff turnover

* CV as a personal activity rather than the workplace

* Lack reward-recognition-valuation of CV

* The main job characteristics

* Low overall participation of the company in CV

* Level of participation of coworkers and peers

* Inability of employee to choose the cause

* Levels of internal and external communication

SOURCE: Prepared by authors.

\section{Lack of government support and tax incentives}

Lack of government support and/or lack of tax for $\mathrm{CV}$ development incentives can become an obstacle to the implementation of $\mathrm{CV}$ programs. It can also mean a lower allocation of resources for these 
programs; and this, at the same time, can become a brake on employee participation. This is like several participants of the Focus Groups reflected who thought that tax advantages as the greater motivation of the company to develop this type of programs. In this regard, the literature states that CV, as CSR practice, is conditioned by standards, regulations, and government fiscal measures (Aguinis and Glavas, 2012; Smith, 1994), which can encourage the development of these programs.

\section{Low external pressure on the organization}

If the company lacked this outside pressure is possible that it would be less motivated to develop social activities: "I think CV is good because it allows us to gain new customers against the competition", one participant said. Indeed, pressure from stakeholders and third-party evaluations are related positively with the implementation of CV programs by the company (Aguinis and Glavas, 2012).

\section{Low level of worker satisfaction and lack of involvement}

The situation of employees dissatisfaction can be a significant barrier to their participation in CV. "I do not participate in CV, among other things, because I'm unhappy with the fact that the company encourages us to be here until 8 pm as if our work depended on someone's life, as if we were surgeons or we were to save the world. We could go all at $7 \mathrm{pm}$ and nothing would happen, but nobody does it", said another employee. In this regard, we realize that it will be difficult to participate in CV programs for some unmotivated employees because they believe that the company does not deserve it; although paradoxically we also see that there may be a risk that unmotivated employees and /or who want to leave the company, regularly participate in the activities of $\mathrm{CV}$, because these activities are more fun than being at work. There is also a positive association between participation in CV and job satisfaction (De Gilder et al, 2005; Lorenz et al, 2011).

\section{Insufficient identification of workers with the organization}

"I like listening to people who we have helped, wondering when we will see each others again; valuing that you have gone; that they want to see you again; and keep whatever they have received from us: I am proud of the company for what it does. Other companies where I have been, they don't do that", said another employee. Exercise of CV can increase worker identification with the organization (Aguinis and Glavas, 2012); and a greater commitment by the worker tends to increase company results (Muller and Kraussl, 2011). Thus, CV as CSR activity has a direct and positive relationship with the pride of belonging and the perceptions of the organizational support; and it is related indirectly and positively with organizational identification, with job satisfaction and effective commitment that goes beyond the terms of the contract; and reflects the ethical climate of the company (El Akremi et al, 2015).

\section{Not consider contextual variables}

Reasons do not operate independently on the context (Kim et al, 2013). Contextual variables - such as the corporate culture and its CV project - are key to employee participation in CV (Vaidyanathan, 2008), since the organizational context modulates potential barriers, and there may be differences in employees depending on the complexity of the organization. Thus, it is important to consider the contextual variables derived from the company's own CV project, such as motivation and autonomy of the 
tasks, and the congruence between employee and NGO values; (Van Schie et al, 2015). These three factors may increase or reduce the level of the predictive variable self-determined motivation, as we know, both the level of involvement of employees and OCB behaviors (Van Schie et al, 2015).

In relation to these three variables -motivation, autonomy and congruence- the FG participants saw as an insurmountable barrier to their participation the non-congruence between their own values and those of the addressee of the action -or the NGO benefiting from CV company activities-. For example, several of them do not go to activities related to animal support because they have other priorities. For others, it has been an insurmountable barrier to going to CV activities where they carried out tasks that were not motivating, tedious, not challenging; or where they could not bring value; so they have decided not to participate again. Thus, some participants manifested in this way in relation to voluntary environmental activities where they have participated. Likewise, the autonomy limitation in the development of CV tasks supposes another serious barrier, as emphasizes other participant in relation to his CV experience in a social dining room.

In addition to these variables, it would also be necessary to consider others contextual variables such as organizational culture and justice, hierarchical structure, team cohesion, internal communication (Van Schie et al, 2015) and social context (Bowman, 2004). If they are not taken into account they can constitute brakes or barriers to participation. In relation to these variables, in the FGs we detected certain points to which we refer below.

As it might be expected, OCB has a very direct connection with aspects of organizational justice. There are four types of this kind of justice: 1) distributive; 2) procedural; 3) interpersonal; and 4) informative. Meanwhile, Leventhal criteria regarding to the procedural justice are the following six: 1) consistency; 2) impartiality; 3) application for decision-making; 4) monitoring and correction; 5) ethics; and 6) stakeholder orientation (Colquitt, 2001). Folger and Bies (1989), in this regard, point out seven elements that managers can use to promote procedural justice: 1) process control; 2) bias suppresion; 3) consistency; 4) feedback; 5) justification; 6) truthfulness; and 7) courtesy (Colquitt, 2001).

Additionally our research shows the desirability of a syntony between values, culture, company way of acting, its CSR strategy; and specific social and CV action programs along the lines of Chen and Hung-Baesecke (2014). This is affirmed by several participants of the Focus Group who affirm that "CV is in the DNA of the company". Collective culture has a positive relationship with Corporate Volunteering not only as OCB, but also as an Impression Manager Behavior (IMB), when the main workers motivation to participate is to improve their image and influence in the organization (Kim and Lee, 2012). The more implanted CV is as part of the company culture the greater participation.

The results obtained from the FG are similar in the five companies, although some differences have been observed depending on the complexity of the organization. The structure of the organization determines such important aspects as the possibility of employee participation, and may be a brake to such participation. Some participants - for example, more dedicated to production tasks or customer service 
- complained about very inflexible work shifts that prevented them participating in CV. In this sense, we cheeked in FG that the hierarchical structure of the organization can affect its internal communication; and thus, it can be carried out by departments of CV, CSR, Marketing or Human Resources. Insufficient communication is a serious barrier to participation. The FG participants seem to take more into account the internal communication coming from CSR or CV department. It seems that they interpret that the company takes this activity more seriously if it has a department that dedicates itself exclusively to do that. Although this circumstance is influenced by the size of the company, since it is generally the large companies which have a CV or CSR department to manage these types of projects. On the other hand, it seems that in the smallest companies, informal information among employees about CV activities -which is the most effective- flows more and has more travel. Also we note at this point, the importance of the relationship between the organizational structure, the support of the CEO and the managers to the CV project. Lack of support and involvement avoids the cross-cutting implementation of the project throughout the organization. In this sense, the FGs show that in smaller companies support and involvement of CEO is usually accompanied by managers support in a greater degree than in larger companies

Lack of team cohesion is also a very important barrier, since we have detected that informal communication among employees about the schedule of activities -during periods like food or breakfast- is key to decide to participate in CV. Likewise, participants in the FG report that this communication can also be done between colleagues from different departments and positions. Team cohesion can make easier that informal communication becomes widespread within the company; their absence can be a brake, and so, some participants of the FG state that they prefer to go to activities where their department colleagues do not go to. In addition, as already mentioned, the social context is the basis of asymmetric information (Bowman, 2004). For example, the company cannot expect the same participation in a country with great tradition in this field than in others. "There is less development of CV in our country compared to companies in other countries such as UK, where I have worked before" noted a member of the discussion group.

Recapitulating, we can point out that for the participants, both the circumstance that CV is not integrated into the company culture -an older program can facilitate participation; and the company's own CV project can become barriers to participation. Likewise, lack of institutional justice may be another obstacle because the employee may think that the company is acting in a hypocritical way. Undoubtedly, an inadequate flow of internal information can also be another important constraint, since participants state that they often realize about CV activities once they have finished, and through colleagues who have participated. In the same way, it is necessary not to ignore the social context, nor that a non-cohesive team can pose another barrier to participation; and above all, that the complexity of the organization can condition that certain factors can be converted into brakes too. In short, we have seen the incidence of contextual variables in employees motivations to participate in $\mathrm{CV}$, whence we can say that clearly the organizational context modulates the possible barriers and there are differences in employees depending on the complexity of the organization. 


\section{Lack of management commitment: CEOs and Managers}

Undoubtedly, one of the main barriers to employee participation is lack of support from managers. "If there is a meeting and I don't go because I'm in a volunteer activity, I do not know how my boss would take it", said another employee. "I do not participate because I never hear my boss talking about volunteering in any meeting. This is a topic that is not of my department", said another. "If the CEO of your company does not support you to go to CV I interpret it as: you do not go, stay here and do not waste much time", said another employee. "While I'm in one of these acts, my boss is sending me thousands of emails: not like this!" noted another one. CEO and managers support can dramatically influence the participation of employees in CV (Benjamin, 2001). The literature offers a new generation of managers concerned about society and sustainability. Thus, CSR activities, such as CV, may be associated with personal and changing values of the managers; they could bet on developing projects that address their moral concerns, and even inspire their employees to get involved in the community even without formally establishing a culture of CSR in the company (Hemingway and Maclagan, 2004). The importance of this barrier was reflected in the FG, in the case of a very active worker in CV -who had changed from department recently- and he could not participate in CV activities because his manager was not too aligned with CV project. This caused some frustration and demotivation to the worker because he had being in contact with some of the beneficiaries of the program for years.

\section{"Good soldiers" and "good actors": lack of support}

As stated above, the reasons for prosocial values are likely to predict OCB. Employees, as we know, can act moved by what is called the behavior of a "good soldiers", or by a key strategy of a "good actor" who seeks to impress their managers (Ariani, 2017). Therefore, although the OCB assumes that employees are involved in these behaviors as "good soldiers" and acting on behalf of the employer, they can also seek their own interest to improve their own image and to be in good terms with their superiors (Bolino, 1999). In this sense, one of the participants said: "CV can improve my career and the image my superiors have on me". "You can have positive consequences in the relationship with your boss; see yourselves identified with the project; then, you can speak about the project and feel closer", said another. "It can be positive because then you see the human part of the CEO you can not see at work. It allows you to have some time with him to chat in a different situation from what you usually have", said another employee. "It is good to meet with partners, see the CEO there, chat with them, and see you," said one of the participants. "I like activities that are more visible, where my company is committed to helping others. I am proud of the company. Being proud of what we do also motivates. It is something that not all companies offer and we have the opportunity. I like to take advantage of if', said another employee. Similarly, it is paradigmatic how Coca-Cola defined its rebranding strategy, based on CV: employees as ambassadors of the company wore T-shirts with company logo while participating in these programs (Barkay, 2012). An employee whose main motivation is to impress the managers, and does not find recognition in their voluntary work by them, can be slowed down to participate. "CV is something personal, nothing to feel pride of representing the company; if I went, I would be proud of myself, not of the company. I do not think it has to have any consequences on my relationship with my boss or with the CEO: it is voluntary", said another employee. In this way, we appreciate that lack of motivation to impress managers does not represent a brake in itself. 


\section{Sense of obligation}

Another important barrier to participation in CV programs can be constituted by the sense of obligation that employee can feel: "In my company, there is some obligation to participate in the events; I think that if you are forced to go to these things, it is totally counterproductive; I do not go", noted one. In short, if the employee perceives CV as mandatory it may have a high negative impact on those who feel less willing to participate in (Stukas, 1999).

\section{Inability to express their values}

As mentioned above, the opportunity to express their own values is one of the main motivations of employees in order to participating in CV. A program that does not provide them with that possibility can become a barrier to participation: "I have often thought of helping and collaborating but it is difficult to find an organization; if the same company organizes it; much better". Volunteering allows employees to express their personal values (Lorenz et al, 2011), show their talents and knowledge (Bolino, 1999). For proper development, there must be congruence between individual values and values of the organization (Aguinis and Glavas, 2012). "I do not consider that the program actually helps because it just allows you to go once a year to help. After that, you leave them (beneficiaries)", one of the participants stated.

\section{Lack of social awareness and internal training on volunteering}

Employees value information and awareness gained by CV. In particular, they appreciate the training that eventually get. "The speeches of NGOs in the company have surprised me: They are very interesting ... I did not know how to help. They teach you how you can do it". However, lack of training can become another barrier to employee participation in these programs. "By our lifestyle inertia for us it is hard to remember that there are people who need help, and it does not too much", said another employee. Moreover, we note that the introduction of volunteer training programs can develop the involvement of employees (Jain et al, 2012); and that CV can be seen as a resource that allows the company to train their workers at low cost (Caudron, 1994).

\section{Negative perception of CSR by the employee}

Ignorance or poor perception of CSR by the employee may have negative consequences in their participation. "I do not consider that the company has a CSR department to help society, but to improve its image. I do not want to play that game". According to the Theory of Signaling, employees participation in CV programs allows them to have greater knowledge of these activities that stand as examples of the strongest concern of the company by society (Sheel and Vohra, 2016): "This company is more responsible than others which I have been by all means". Employees participating in CV have more meaningful perceptions of CSR company (Sheel and Vohra, 2016). How the worker perceives CSR is a mediating factor in the relationship between the development of ethics programs in the company and job satisfaction (Valentine and Fleischman, 2008): "CV helps me to value my job because there are other companies which do not have it. I talk to my friends and many would love to come. " 


\section{CV perception as Public Relations and skepticism in employees}

The fact that the main motivation of the company in developing a program of $\mathrm{CV}$ is to improve their image or make public relations also is an obstacle to participation: "I do not participate much. I think the target of $\mathrm{CV}$ is the image, communication, photographs of activities: Come on ... like a marketing activity!". Paradoxically, those companies that prioritize the motivations of public relations in order to generate profits through $\mathrm{CV}$-as a philanthropy activity-are losing the opportunity to create social value (Porter and Kramer, 2002). We have also detected in our investigation that there are employees who believe that the main motivation of the company to implement CV programs is a tax relief. This can also generate skepticism and distrust, and it is a serious barrier to their participation in the program. Conversely, if workers perceive that the company really cares about social problems, the level of skepticism and distrust would be significantly reduced (Sheel and Vohra, 2016). Furthermore, we note that following Maslach et al. (2001), the more labor involvement, the less stress levels, less fatigue, less inefficiency and less doses of skepticism.

\section{Program designed and organized incorrectly}

A program that is not well designed, well organized and properly communicated, reduces the likelihood that the workers are involved in. Some of the possible errors are covered in this chapter. It is therefore necessary, a plan to support and encourage CV (Geroy, et al, 2000). So in our research, we have seen that there are employees who do not participate because they consider that the programs has limitations, like for instance, of the range of causes in which they can be involved; resources provided by the company to develop these activities; or any of other brakes that we are considering in this section.

\section{Prior poor personal experience}

A previous negative experience in $\mathrm{CV}$ activities can become a very difficult barrier to beast: "I do not usually go because, to go to activities sometimes give me a bad time emotionally. It is a very strong crash in your daily reality". Voluntary employee acquires a sense of program activities cognitively build and based on their own previous experiences (Liao-Troth and Dunn, 1999).

\section{Lack of financial and material resources}

Lack of resources does not encourage the employee participation in these programs. We have found that lack of resources, especially transport, is an important employee participation barrier. This because the employee does not have these resources, or considers that the employer - as promoter activity- should provide them: "The company should pay for transport costs, petrol, mileage or food of CV activity; it is a very important impediment for me". Before deciding whether or not to participate in a CV program, somehow, employees carry out an analysis of costs that could be involved and the potential benefits that they would expect. To higher profits and lower costs, greater incentive to participate (Penner et al, 2005). We have also found that, if the costs and inconvenience involved in participation in a particular activity, outweigh the potential benefits of this activity, the employee can feel laziness or lack of sufficient motivation to get involved into the project. 


\section{Lack of time}

Our results are consistent with the literature in which time is the main barrier to the employee involved in CV (Geroy, et al, 2000); and we can relate it to lack of effective support from managers. The new nuance we have found is that although the employees should have -in theory- a specific number of hours a month to volunteer, it may not be so in reality, because the missing hours of CV have to be made up later anyway. This involves expanding their schedule or that other colleagues have to deal with the task that the volunteer does not do; "It would be good that they (managers) thought that you are not around that day, like it was a vacation day. It seems that the hours I've been away, I should have been working. They have not giving me less tasks, but the same as if I had been there that time", one of the participants noted in this regard.

\section{Not consider employees motivations}

As mentioned, lack of employees motivation is a major barrier to increase their participation: "What motivates me are animals, and fight again animal abuse that they suffer in large cities. I think my company does very little of this", said an employee. Also, it should be taken under consideration that worker motivation to begin participating in $\mathrm{CV}$ is different to worker motivation to continue engaging in $\mathrm{CV}$ (Grant, 2012).

\section{Program unable to satisfy the functional needs of employees}

As indicated above, the reasons for employees to participate in CV may also be functional. That is, the employee gets satisfaction in exchange of covering needs for: 1) values -altruism-, 2) understanding -learning experiences-, 3) social experiences, 4) carreer -professional skills-, 5) protection ego and guilt for being luckier-, and 6) enhacement -satisfaction by staff development and self-esteem(Clary et all, 1998). In this regard, an employee said: "I go with the certainty that, the activities where I am going to participate in will be a good experience to me: I help, they are fun and I going to learn things. Otherwise, I do not suggest it".

\section{Little contact with beneficiaries: proximity, intensity and frequency}

Volunteers who may have direct contact with the beneficiaries may experience biological mechanisms related to more intensive care given systems (Konrath, 2014). In our research, we have appreciated that the fact that the volunteer cannot interact -or have a high physical contact with beneficiariesit is not a serious barrier to participate: "I would rather be in direct contact with people who I help but it is not something relevant for me". However, a low frequency of contact itself appears as a brake: "for me, it makes little sense because we go to help a particular ONG once a year. Organizations we have visited have their regular volunteers and do not depend on whether we go or not; this is the reason why I do not usually go". While proximity with the beneficiary can motivate workers to participate in CV, we have noticed that a low intensity of contact does not appear to be a brake on employee participation.

\section{Reduced impact on others}

It appears from our research, the impact level of voluntary action is a motivating factor. This assessment is consistent with the literature. On the contrary, a small impact of employee participation can be 
an obstacle too. The more they can contribute and impact others, greater satisfaction will be delivered: "When you know a project that catches your attention, in which you feel most useful or where you can provide more from your knowledge, -as in my case, speeches to unemployed people- I used to go for if'. Then it is important that the company knows how to design programs that allows workers to use their skills and strengths. The greater impact on others, the greater task significance (Humphrey et al, 2007).

\section{High staff turnover}

One of the greatest virtues of $\mathrm{CV}$ is that employees recommend their company to other potential workers. There is no doubt, that it also increases motivation and promotes the development of their skills (Tuffrey, 2003). On the other hand, a high staff turnover can also be a brake to participation by making it hard to the stability and employee involvement with the company. So one participant expressed it: "The high turnover that we have in the company is not good for the program: when an employee begins to know it and become familiar with it, he is going to another firm".

\section{Interpretation of CV as a personal activity rather than the workplace}

There are employees who interpret CV as a teambuilding activity within the scope of work. Others interpret it as a personal and altruistic activity of their lifestyle. They consider that it should not be financed by the company, and that the money spent could be used alternatively in their own interests (De Gilder et al, 2005). Conceiving volunteering as an option to develop on a personal level and not at working level may constitute a serious obstacle to participation: "I separate my concerns to help others, from my subjects of work: I think volunteering is a very personal thing".

\section{Lack of reward, recognition and valuation to volunteer employee}

The company may also include CV contributions from employees in performance evaluations, but can also recognize the best employees by, for example, organizing CV events (Ghosh and Gurunathan, 2014). However, our research shows that employees do not agree with that participation in CV is included in performance evaluations, because they consider that it may adulterate the voluntary character in some way. In this sense, CV awards ceremonies is a form of motivation and a way to encourage employees participation based on emotion, dynamism and enthusiasm (Galia, 2015): "I really like this kind of event: they encourage you to participate, "said an employee. "You see what each partner has participate in; see what it has been done this year and you are motivated to participate in more activities", another worker commented. In a rhetorical level, managers value employee involvement in the community. In a practical level, they seek to improve employee perceptions of CSR activities of the company and encourage them to participate in CV. While in an interpretation level, those events seek to communicate expectations regarding CV and other CSR activities. Moreover, we have not found in our research, that lack of reward, recognition or valuation of volunteer work, could be a significant brake to continue volunteering. Moreover, conversely, some of our participants considered that rewards itself -actually- can be a hindrance because it could undermine the voluntary nature of program participation: "It is good that the company values to volunteer work, but if there is an extra contribution to go, I think its essence is lost ... Although it is a way to encourage participation too". "It should be 
assessed by the company," noted another: "I do these things because I want: I do not expect recognition ... I feel good helping; I like to help, but do not expect recognition".

\section{Characteristics of the job}

The complexity of job tasks makes the participation in volunteering more likely (Wilson and Musick, 1997); but, on the contrary, Compensation Theory says that workers can practice volunteering to compensate for lack of meaning of their work (Rodell, 2013). Our research appreciates that relational or significance deficiencies in employees jobs like a motive to participate in CV programs; but we have not found evidence that the design of the workplace constitutes -for its high significance or for its simplicity- a brake to participation.

\section{Low overall participation of the company}

Subjective norms may suppose some pressure to employee participation in CV, and thus the number of members of the organization involved in CV program can encourage individual participation (Henning, 2008). A low participation of peers can be another obstacle for CV: "I do not participate in my company because people do not do like that: it is something that does not reach us."

\section{Coworkers and colleagues from other departments participation}

The participation of coworkers can become a brake because employees prefer to go with colleagues from other departments in order to meet new people. This is usually the case, except in the early stages of CV and complex activities where workers prefer to go with their regular partners. The reason is that they feel more comfortable with them and have more confidence. In these cases, the participation of coworkers could be a driving force to participation. "I'd rather not go with my teammates. I like to go with colleagues from other departments. I appreciate the interrelationship especially in activities that are not very difficult". This coincides with that coworkers participation has a negative effect on CV (Peloza et al, 2009): "I think we should encourage the activities organized by employees themselves: so they would have a circle that would be easier to move. Involve more people in "before CV" rather than the "after CV", in the design of the program ... is the typical colleague who tells you every single day: come on, sign up! It would encourage me more at least", said another employee. Coworkers support is more powerful psychologically than organizational support, since coworkers are closer to employees than organization situational determinants. Thus, CV occurs more likely if interpersonal reasons or supporting coworkers are high (Kim et al, 2013)." The first time, you likely go with someone from your department with whom you have more confidence; and after that, you do not care about it". In this way, we realize that employees with low confidence can begin to volunteer if they are recruited by peers rather than on their own initiative.

\section{Impossibility of choice cause}

"I'd rather go to activities where we can help disabled people: it seems like your work is more useful", noted an employee. Various studies highlight the preferences of employees to help certain groups at risk of social exclusion, like the preference of some companies to develop activities on topics such as disability, childhood and education (Gallardo et al, 2010). In our research, the impossibility of choos- 
ing the cause from the employees is not a brake on their participation: "Further than the cause, what limits me the most are other factors: mainly, lack of time available. I like some particular groups more than others; but in my opinion, to be able to choose it, it is not decisive to participate", said another employee.

\section{Internal and external communication}

Lack of internal communication and an excessive external communication of CV program can be an important brake for employee participation. Lack of internal communication about activities is a widespread brake, which has been identified in our investigation. In fact, employees ask to increase communication via intranet, or through meetings and speeches: "in order to help people, you must be informed of what you are going to do. There has to be good communication within the company so you know what you can contribute and what will you do. If I am not well informed, because of laziness, I don't usually go". Communication is so important that even all employees that know the program although do not participate- are more likely to recommend the company to other potential employees. It is also likely that they feel more motivated than those who do not know it. Similarly, oldest and most experienced employees have more knowledge about CV programs, which makes necessary to communicate from below in order to younger employees know CV project in deep (Tuffrey, 2003). The employer also has to communicate the expectations of the company in relation to their CSR activities (Galia, 2015). Media impact of CV activities can have a positive impact on employee involvement too (Smith, 1994; Vaidyanathan, 2008). However, in our research we have not found that lack of external communication represents a brake to participation. On the contrary, we have observed that there are employees who feel that the company communicates to outside its CV activities in excess; and they interpret this as proof that the main aim of these programs is none other than to improve company image. This, as mentioned above, can generate cinism and disturb. In this sense, an excess of advertising would constitute a brake to employees take on board in CV programs. 


\section{4.- Discussion, scope and future research}

In this section we will perform a ranking of the brakes and barriers detected in the FG, explain which are the most important and why; and we will see the relationship between them.

First, we ran a ranking of the 28 possible barriers and brakes to employee participation detected in the FG. The criteria followed was the degree of difficulty to overcoming the participation of each brake and barrier. In this way, as Figure 3 reflects, we obtained four groups: 1) very high difficulty to overcoming; 2) high difficulty to overcoming; 3) moderate difficulty to overcoming; 4) low difficulty to overcoming. In turn, we group the first two of them under the category of barriers; and the last two groups, under the brakes category, due to the least impediment that they suppose.

\section{Figure 3. Conceptual Model CV: barriers and brakes possible to employee participation in CV}

\begin{tabular}{|c|c|}
\hline \multicolumn{2}{|c|}{ Possible BARRIERS and Brakes on Participation } \\
\hline 1. VERY HIGH difficulty to overcoming & 2. HIGH difficulty to overcoming \\
\hline $\begin{array}{l}\text { * Lack of time available to participate in CV } \\
\text { * Lack of management commitment: CEOs / managers } \\
\text { * CV as a personal activity rather than the workplace } \\
\text { * Insufficient workers identification with company } \\
\text { * Low levels of satisfaction /employee involvement } \\
{ }^{*} \text { Negative perception of CSR by the employee } \\
\text { * CV perception as PPRR/employee skepticism }\end{array}$ & $\begin{array}{l}\text { * Not consider employees motivation } \\
\text { * Program does not meet the functional needs } \\
\text { * Impossibility to express employee values } \\
\text { * Lack of social awareness / internal training } \\
\text { * Prior poor personal experience in CV activities } \\
\text { * Reduced impact of voluntary activities } \\
{ }^{*} \text { Inappropriate level of internal communication }\end{array}$ \\
\hline
\end{tabular}

\begin{tabular}{|c|c|}
\hline \multicolumn{2}{|c|}{ Possible BRAKES on employee participation Corporate Volunteering Programs } \\
\hline 3. MODERATE difficulty to overcoming & 4. LOW difficulty to overcoming \\
\hline $\begin{array}{l}\text { * Program designed and organized incorrectly } \\
\text { * Lack of financial resources and material resources } \\
\text { * Feeling of obligation or pressure to participate } \\
\text { * Disregarding possible contextual variables } \\
\text { * Lack of support to "good soldiers"/"good actors" } \\
\text { * A very high company staff turnover } \\
\text { * Little contact with beneficiaries of the program }\end{array}$ & $\begin{array}{l}\text { * The main own job characteristics } \\
{ }^{*} \text { Low overall participation of the company in CV } \\
{ }^{*} \text { Level of participation of coworkers and peers } \\
{ }^{*} \text { Inability of the employee to choose the cause } \\
{ }^{*} \text { Lack reward-recognition-valuation of CV } \\
{ }^{*} \text { Lack of government support and tax incentives } \\
{ }^{*} \text { Low external pressure on the organization }\end{array}$ \\
\hline
\end{tabular}

SOURCE: Prepared by authors. 
The first group includes those barriers that are very difficult to overcome. This is the lack of time, managerial support, consideration of Volunteering as an activity of the private activity, insufficient identification of workers with the company, low satisfaction and involvement, negative perception of CSR of the company as public relations. For its part, the second group encompasses those barriers that are difficult to overcome. Thus, the non-consideration of worker motivation, lack of satisfaction functional needs, impossibility of expressing their values, lack of awareness and social formation, previous poor experiences in CV, activities with little impact, and insufficient internal communication.

Additionally, in a third level, those brakes which difficulty to overcoming for participation is moderate are included. This group consists of the incorrect design and organization of the program, lack of financial and material resources, sense of obligation to participate, lack of consideration of contextual variables, lack of support for "good soldiers" and "good actors", high turnover of the staff, and lack of contact with the beneficiaries of the program. Finally, the fourth group contains the brakes which difficulty to overcoming for participation is low. Then, we have not found evidence that the inability to interact or have a high physical contact with beneficiaries can be a deterrent to participation. We neither have not found evidence that other variables such as job design -because of their high significance or its simplicity-, the impossibility of cause choice by the employees -although some may prefer to choose it-, and lack of recognition of employee volunteer work might become brakes to their participation. It should be noted also that according to contextual variables -previously commented- a barrier could pass to belong from one group to another; for example, from being categorized like moderately overlapping (group 3) to having a very high overcoming difficulty (group 2).

The participants of our study agree with the literature (Geroy et al, 2000) that the main barrier is lack of time. The time barrier is related to other barriers such as the provision of scarce resources, failure to consider the motivations and functional needs of employees or the absence of managerial support. But why with similar limitations of time are there colleagues who overcome this barrier and decide to participate and others not? Employees can decide to spend their little available time in CV if the company is able to organize the program so that employee participation is simplified as much as possible. Thus, for the employee, costs of materials and transportation arising from their participation are reduced. And, if the company is able to maximize the potential benefits (wellbeing, social contacts or career) that the employees get from participate in CV, it would be easier that they overcome their lack of effort or the "laziness" to participate. In this sense, some participants of our study maintain that lack of time is really just an excuse for not participating. Also, it has been shown that, the employer does not really know the motivations that guide the employees to participate in CV; and neither, they knew how to detect which are the brakes to participation in order to mitigate them. In relation to the time barrier, our research contributes highlighting the idea that although employers provide working hours to employee participation in these programs, workers can consider this as a fallacy due to the fact that, after participating in CV activities, they should make up for the work undone so they decide not to participate. 
The second most important barrier that the FG collects is the lack of managerial support. At this point, we highlight the appreciated difference between the roles played by the CEO and managers. The CEO has a role of boosting and supporting the company's social programs as well as their own recognition; and managers -in the case of CV- have the mission of facilitating the participation of their teams in the projects of $\mathrm{CV}$. If not, lack of managerial support can become an insurmountable barrier. Thus, this barrier is related to the lack of time, as we have just seen, but it can also be related to other barriers such as poor design of the program, lack of resources or previous poor experiences.

In respect of lack of management support barrier, our research contributes to point the obstacle that suppouse those managers who -in a more or less conscious way- do not reduce volunteer work load; do not facilitate the distribution of their tasks, and even suggest that participating in CV projects constitutes lack of fellowship. Moreover, in this sense and contrary to the idea of De Gilder et al. (2005), we argue that the increase in the workload caused by the absence of workers who is in a CV activity can generate discomfort among the rest of their colleagues. In view of this divergence, we believe that further research on this subject may be necessary.

Then, managers lack of support is one of the main barriers to employee participation because employees who do not have their direct managers support to participate can interpret that attending to these events could have negative consequences in their career, such as the manager may come to think that they do not have enough load of work or that their positions are dispensable. Without managerial support it is very difficult to implement a CV program transversally, that is key to achieving good rates of employee participation.

Let's finally see some relationships between barriers in addition to those already mentioned previously that may occur within each group. In the first group, barriers that imply lack of identification, satisfaction and employee involvement are related. Employees who have these shortcomings are complex to participate in CV. We also see that there is a relationship between poor CSR perception barrier and CV used just for company image purposes. Paradoxically, also in line with De Gilder et al (2005), we have seen that lack of support from managers -even not openly declared- can attract employees who want to leave the company or forcing to be fired -because they are aware of that CV practices can have negative consequences for their career and they are not afraid of retaliations, but rather the opposite. Similarly, it is unlikely that dissatisfied, unmotivated, little involved employees -and also those workers little identified with the company-, decide to join such programs. Now if for any reason, as for example the pressure exerted by their coworkers, these employees decides to take the step and participate in $\mathrm{CV}$, the image that they have of their own company could improve while they probably increase their level of motivation.

Summarizing the relationships of other three groups, we realize that in the second group, low impact and previous bad experience usually go hand by hand too; as well as those related to lack of motivations consideration, needs and expression of values by the employees. In the third group, brakes such as poor program organization are related to lack of resources and poor contact with beneficiaries. And 
feeling of compulsion can be related to lack of support for "good soldiers" and "good actors". Last, in the fourth group we can highlight the relationship between a low participation of the company and coworkers and peers participation level in CV activities.

Referring now to the limitations of the study, the number of participants - thirty - that constitute our research could be interpreted as a limitation. Although, regarding the scope of our study, we should insist that our goal was to present a conceptual framework about possible barriers and brakes on workers participation in CV. This is a qualitative and exploratory study that seeks social significance of these brakes and barriers for employees in CV, but it does not seek statistical representation, geographic, industrial, nor whatever kind. In relation to future lines of research that complement what we are analysing, it would probably be worthwhile to make a quantitative methodological contribution in order to study if there are differences depending on the companies complexity of the study in relation to ours. Likewise, we could research the figure of the CEO and their interaction with managers in relation to $\mathrm{CV}$. Specifically; it would be worthwhile looking for answer to which are the determinants and strategies that can be used to achieve the involvement of managers of different department in CV.

\section{5.- Conclusions}

In order to finish answering the research question adequately, in this section we will explain what are the key factors of CV and the most common barriers in other voluntary activities; moreover we will show the reason why lack of managerial support is one of the most important barriers in CV, and we will point out the barriers to employee participation in CV that differ - or are different- from barriers to employee participation of other corporate projects.

When participating in a voluntary activity, people can have multiple reasons which can affect their decision. According to Peterson (2004), some of them are functional reasons and others respond to related issues with the organizational structure, job satisfaction, autonomy and self-determination.

Additionally, Peloza and Hassay (2006) indicated the differences between motivations that move the volunteers involved in $\mathrm{CV}$ and the volunteers who perform their voluntary activity outside the organization -Extra Organizational Voluntering (EOV) or which is developed in the private scope and without being linked to the company-. For these authors, CV is different from traditional forms of Volunteering. The desire to help others prevails less in $\mathrm{CV}$ than in other forms of private volunteering. Private Volunteering is motivated in part by altruistic motives, whereas CV does not. Traditional volunteering depends on context and tasks as well. But, considering the relationship between both, it should also be noted that participation in CV does not increase participation in private voluntary service. 
In relation to private volunteering, the main barrier for volunteers to decide not to remain in the longterm NGO -one of the main entitle objectives- is to feel pressured and be very controlled by the NGO supervisor (Stukas et al, 1999). In addition, even granting autonomy, if the tasks that the NGO asks the volunteer do not motivate enough or there is an inconsistency between their values and the NGO's values will also be another barrier very difficult to overcome in order to maintain the participation of the volunteer (Van Schie et al, 2015).

Therefore, as we have commented, CV is a commitment of time and effort (Wilson, 2000) without coercion or compensation (Millette and Gagné, 2008). And key factors that differentiate CV from public volunteering are employer-employee intermediation and attitudes towards the employer (Jones, 2010), such as the motivation to impress managers (Grant and Mager, 2009), or being a good member of the company (Peloza and Hassay, 2006).

Lack of managerial support is one of the main barriers to employee participation in CV because it impedes the cross-cutting implementation of the project in order to reach all employees of the company. That means, this barrier prevents the correct "coming down": from the top to the bottom; from the CEO to managers, from the latter to the intermediate positions to reach finally the rest of employees. To achieve greater participation it is necessary first that the CEO figure drives and supports CV program, and then that managers facilitate this participation. In this sense, if employees do not have the support of their managers, it is difficult they take the decision to participate.

Managers not aligned with CV can communicate their lack of support to their teams directly or expressly; but also in a more subtle or indirect way. For example, organizing convening meetings just at the same schedule for the $\mathrm{CV}$; or sending numerous mails with various tasks that the employee must perform during the hours in which the employee is participating in CV. In this sense, as CV is a project developed and driven by the company itself, managers can choose this second way to avoid possible clashes with their superiors or with those responsible for the CV Program of the company.

This circumstance can be interpreted by the employee as a company inconsistency; or as if the company had ulterior motives to develop CV programs. This certainly can lead to distrust and lack of motivation; especially in employees with marked prosocial orientation. This lack of motivation can be a serious risk, not only because together with other factors, could be decisive for the employee decision to leave the company.

Barriers to participation in CV can be common -but with their own particularities and possibly assuming different levels of overcoming difficulty- to barriers to employee participation in other company projects; except of some exceptions derived from the own CV concept.

In this sense, from very high difficulty barriers, lack of time, lack of management involvement, absence of identification, satisfaction and involvement of the employee, as well as the negative perception of the department in question and of the purposes of its own activity could also be common 
barriers that could impede employees participation in other projects of the company. However, the vision of CV as a private activity that should not be mixed with business activity can be an exclusive barrier of $\mathrm{CV}$.

At the same time, from the second group of barriers - those with high difficulty to overcoming - perhaps we could consider as exclusive barriers of the scope of CV the non-consideration of the functional needs of the employee and lack of sensitization, because they are not contemplated in other areas of the company . Non-consideration of employees motivations, inability to express their values, lack of training, previous negative experiences, and lack of impact and communication of projects are barriers that could be extrapolated to other projects of the company too.

Likewise, most brakes considered - of moderate and low difficulty to overcoming - could somehow be interpreted as brakes of employees participation in other corporate projects, perhaps with the exception of the feeling of compulsion to participate - since they can be enforced by being within the duties and functions of the employee.

At this point, finally we consider that we are able to respond to the research question that motivates us. Then, the company must promote or align with those motivations and factors that are determinant for employee participation; and must be able to reduce the barriers and brakes that preclude such participation. In this way, the proposed model allows to advance in the knowledge of the Corporate Volunteering field - as was required in the literature - at the same time that offers to companies managers a framework to be able to implement Volunteering Programs mitigating possible risks, and effectively increasing the employees participation.

\section{6.- References}

AGUILERA, R.V., RUPP, D.E., WILLIAMS, C.A. \& GANAPATHI, J. (2005): "Putting the S back in corporate social responsibility: A multilevel theory of social change in organizations", Academy of management review, 32(3), 836-863.

AGUINIS, H. \& GLAVAS, A. (2012): "What we know and don't know about corporate social responsibility a review and research agenda", Journal of management, 38(4), 932-968.

ARIANI, D.W. (2017): "Good Soldiers and Good Actors: Is there Any Differences?", International Journal of Asian Social Science, 7(1), 31-44.

BARKAY, T. (2012): "Employee volunteering: soul, body and CSR", Social Responsibility Journal, 8(1), 48-62. 
BARTSCH, G. (2012): "Emotional learning: managerial development by corporate volunteering", Journal of Management Development, 31(3), 253-262.

BATEMAN, T.S. \& ORGAN, D.W. (1983): "Job satisfaction and the good soldier: The relationship between affect and employee 'citizenship"', Academy of management Journal, 26(4), 587-595.

BENJAMIN, E.J. (2001): "A look inside corporate employee volunteer programs", Journal of Volunteer Administration, 19(2), 16-32.

BLOCK, E.S., GLAVAS, A., MANNOR, M.J. \& ERSKINE, L. Business for Good (2015): "An Investigation into the Strategies Firms Use to Maximize the Impact of Financial Corporate Philanthropy on Employee Attitudes", Journal of Business Ethics, 1-17.

BOCCALANDRO, B. (2009): Mapping success in employee volunteering: The drivers of effectiveness for employee volunteering giving programs and Fortune 500 performance, Boston College Center for Corporate Citizenship. http://www.bcccc.net/document/docWindow.cfm?fuseaction=document.viewDocument\&documentid=1308\&documentFormatld=2312, acesso 15 diciembre 2015.

BOLINO, M.C. (1999): "Citizenship and impression management: Good soldiers or good actors?", Academy of Management Review, 24(1), 82-98.

BOWMAN, W. (2004): "Confidence in charitable institutions and volunteering", Nonprofit and Voluntary Sector Quarterly, 33(2), 247-270.

BOZKURT, S. \& BAL, Y. (2012): "Investigation of the relationship between corporate social responsibility and organizational citizenship behavior: a research", International Journal of Innovations in Business, 1(1), 40.

BRUCH, H. \& WALTER, F. (2005): "The keys to rethinking corporate philanthropy", MIT Sloan Management Review, 47(1), 49.

BRUDNEY, J.L. \& GAZLEY, B. (2006): "Moving ahead or falling behind? Volunteer promotion and data collection", Nonprofit Management and Leadership, 16(3), 259-276.

CALIGIURI, P., MENCIN, A. \& JIANG, K. (2013): "Win-win-win: The influence of company sponsored volunteerism programs on employees, NGOs, and business units", Personnel Psychology, 66(4), 825-860.

CARROLL, A.B. (1998): "The four faces of corporate citizenship", Business and society review, 100(1), 1-7.

CATALANO, R.F., OESTERLE, S., FLEMING, C.B. \& HAWKINS, J.D. (2004): "The importance of bonding to school for healthy development: Findings from the Social Development Research Group", Journal of School Health, 74(7), 252-261.

CAUDRON, S. (1994): "Volunteer efforts offer low-cost training options", Personnel Journal, 8-44. 
CECP. Committee Encouraging Corporate Philanthropy (with The Conference Board) 2015: Giving in Numbers, 2015 edition. http://cecp.co/pdfs/giving_in_numbers/GIN2015_FINAL_web.pdf. Accessed March 1, 2016.

CHEN, Y.R.R. \& HUNG-BAESECKE, C.J.F. (2014): "Examining the internal aspect of Corporate Social Responsibility (CSR): leader behavior and employee CSR participation", Communication research reports, 31(2), 210-220.

CLARY, E.G., SNYDER, M., RIDGE, R.D., COPELAND, J., STUKAS, A.A., HAUGEN, J. \& MIENE, P. (1998): "Understanding and assessing the motivations of volunteers: a functional approach", Journal of personality and social psychology, 74(6), 1516.

CNAAN, R.A., KASTERNAKIS, A. \& WINEBURG, R.J. (1993): "Religious people, religious congregations, and volunteerism in human services: Is there a link?", Nonprofit and Voluntary Sector Quarterly, 22(1), 33-51.

COLQUITT, J.A., CONLON, D.E., WESSON, M.J., PORTER, C.O. \& NG, K.Y. (2001): "Justice at the millennium: a meta-analytic review of 25 years of organizational justice research", Journal of applied psychology, 86(3), 425.

DE GILDER, D., SCHUYT, T.N. \& BREEDIJK, M. (2005): "Effects of an employee volunteering program on the work force: The ABN-AMRO Case", Journal of Business Ethics, 61(2), 143-152.

EL AKREMI, A., GOND, J.P., SWAEN, V., DE ROECK, K. \& IGALENS, J. (2015): "How do employees perceive corporate responsibility? Development and validation of a multidimensional corporate stakeholder responsibility scale", Journal of Management, Doi: 10.1177/0149206315569311.

ELLEN, P.S., WEBB, D.J. \& MOHR, L.A. (2006): "Building corporate associations: Consumer attributions for corporate socially responsible programs", Journal of the Academy of Marketing Science, 34(2), 147-157.

FRIEDMAN, M. (1970): The social responsibility of business is to increase its profits, New York, 122124.

GALIA, R. (2015): "Giving From the Heart: The Emotion Management of Volunteering Employees", Studies in Media and Communication, 3(2), 154-163.

GALLARDO, D., SÁNCHEZ, M.I., CORCHUELO, M.B. \& GUERRA, A. (2010): "Diagnóstico del voluntariado corporativo en la empresa española", Revista de Estudios Empresariales, Segunda época, (2), 54-80.

GARRIGA, E. \& MELÉ, D. (2004): "Corporate social responsibility theories: Mapping the territory", Journal of business ethics, 53(1-2), 51-71.

GATIGNON-TURNAU, A.L. \& MIGNONAC, K. (2015): (Mis) "Using employee volunteering for public relations: Implications for corporate volunteers' organizational commitment", Journal of Business Research, 68(1), 7-18. 
GEROY, G.D., WRIGHT, P.C. \& JACOBY, L. (2000): "Toward a conceptual framework of employee volunteerism: An aid for the human resource manager", Management Decision, 38(4), 280-287.

GHOSH, D. \& GURUNATHAN, L. (2014): "Linking perceived corporate social responsibility and intention to quit: The mediating role of job embeddedness", The Journal of Business Perspective, 18(3), 175-183.

GLAVAS, A. (2016): "Corporate Social Responsibility and Employee Engagement: Enabling Employees to Employ More of Their Whole Selves at Work", Frontiers in Psychology, 7, 796.

GRANT, A.M. (2007): "Relational job design and the motivation to make a prosocial difference", Academy of Management Review, 32(2), 393-417.

GRANT, A.M. \& MAYER, D.M. (2009): "Good soldiers and good actors: prosocial and impression management motives as interactive predictors of affiliative citizenship behaviors", Journal of Applied Psychology, 94(4), 900.

GRANT, A.M. (2012): "Giving time, time after time: Work design and sustained employee participation in corporate volunteering", Academy of Management Review, 37(4), 589-615.

GREENING, D.W. \& TURBAN, D.B. (2000): "Corporate social performance as a competitive advantage in attracting a quality workforce", Business \& Society, 39(3), 254-280.

GROZA, M.D., PRONSCHINSKE, M.R. \& WALKER, M. (2011): "Perceived organizational motives and consumer responses to proactive and reactive CSR", Journal of Business Ethics, 102(4), 639-652.

HADDAD, M.A. (2004): "Community determinates of volunteer participation and the promotion of civic health: The case of Japan", Nonprofit and Voluntary Sector Quarterly, 33(3), 8S-31S.

HEMINGWAY, C.A. \& MACLAGAN, P.W. (2004): "Managers' personal values as drivers of corporate social responsibility", Journal of Business Ethics, 50(1), 33-44.

HENNING, J.B. (2008): Antecedents of corporate volunteerism (Doctoral dissertation, Texas A\&M University).

HENNING, J.B. \& JONES, D.A. (2013): Volunteer programs in the corporate world. Using industrialorganizational psychology for the greater good: Helping those who help others, Olson Buchanan \& Thompson (Eds), 110-147.

HERZIG, C. (2006): "Corporate volunteering in Germany: survey and empirical evidence", International Journal of Business Environment, 1(1), 51-69.

HUMPHREY, S.E., NAHRGANG, J.D. \& MORGESON, F.P. (2007): "Integrating motivational, social, and contextual work design features: a meta-analytic summary and theoretical extension of the work design literature", Journal of Applied Psychology, 92(5), 1332.

JAIN, A.K., MALHOTRA, N.K. \& GUAN, C. (2012): "Positive and Negative Affectivity as Mediators of Volunteerism and Service Oriented Citizenship Behavior and Customer Loyalty", Psychology \& Marketing, 29(12), 1004-1017. 
JONES, D.A. (2010): "Does serving the community also serve the company? Using organizational identification and social exchange theories to understand employee responses to a volunteerism programme", Journal of Occupational and Organizational Psychology, 83(4), 857-878.

JONES, D.A., WILLNESS, C.R. \& MADEY, S. (2014): "Why are job seekers attracted by corporate social performance? Experimental and field tests of three signal-based mechanisms", Academy of Management Journal, 57(2), 383-404.

JONES, D.A. (2016): "Widely Assumed but Thinly Tested: Do Employee Volunteers' Self-Reported Skill Improvements Reflect the Nature of Their Volunteering Experiences?", Frontiers in psychology, 7. 495.

KARNANI, A. (2010): "The case against corporate social responsibility", Wall Street Journal, 23, 1-5.

KIM, J. \& KIM, T. (2014): "Multi level Antecedents of Company Support for Employee Volunteering", Corporate Social Responsibility and Environmental Management (23), 37-49.

KIM, P. \& LEE, J.H. (2012): "The influence of collectivism and rater error on organizational citizenship and impression management behaviors", Social Behavior and Personality: an international journal, 40(4), 545-555.

KIM, Y.J., VAN DYNE, L., KAMDAR, D. \& JOHNSON, R.E. (2013): "Why and when do motives matter? An integrative model of motives, role cognitions, and social support as predictors of OCB", Organizational Behavior and Human Decision Processes, 121(2), 231-245.

KNOX, B.D. (2015): Employee Volunteer Programs and Deferred Executive Compensation, AAA 2016 Management Accounting section (Mas) Meeting Paper.

KONRATH, S. (2014): The power of philanthropy and volunteering. Interventions and Policies to Enhance Wellbeing: Wellbeing. A Complete Reference Guide, Volume VI. Edited by Felicia A.

KRUEGER, R.A. (1991): El grupo de discusión. Guía práctica para la investigación aplicada, Madrid, Pirámide.

LEE, L. \& HIGGINS, C. (2001): "Corporate volunteering: ad hoc interaction or route to dialogue and partnership?", Journal of Corporate Citizenship, 1(4), 79-90.

LIAO-TROTH, M.A. \& DUNN, C.P. (1999): "Social constructs and human service: Managerial sensemaking of volunteer motivation", Voluntas: International Journal of Voluntary and Nonprofit Organizations, 10(4), 345-361.

LI, Y. \& FERRARO, K.F. (2005): "Volunteering and depression in later life: Social benefit or selection processes?", Journal of Health and Social Behavior, 46(1), 68-84.

LORENZ, C., GENTILE, G.C. \& WEHNER, T. (2011): "How, why, and to what end? Corporate volunteering as corporate social performance", International Journal of Business Environment, 4(2), 183205. 
LUOH, M.C. \& HERZOG, A.R. (2002): "Individual consequences of volunteer and paid work in old age: Health and mortality", Journal of health and social behavior, 490-509.

MASLACH, C., SCHAUFELI, W.B. \& LEITER, M.P. (2001): "Job burnout", Annual review of psychology, 52(1), 397-422.

MILLETTE, V. \& GAGNE, M. (2008): "Designing volunteers' tasks to maximize motivation, satisfaction and performance: The impact of job characteristics on volunteer engagement", Motivation and Emotion, 32(1), 11-22.

MULLER, A. \& KRAUSSL, R. (2011): "The value of corporate philanthropy during times of crisis: The sensegiving effect of employee involvement", Journal of Business Ethics, 103(2), 203-220.

MUSICK, M.A., WILSON, J. \& BYNUM, W.B. (2000): "Race and formal volunteering: The differential effects of class and religion", Social Forces, 78(4), 1539-1570.

MUTHURI, J.N., MATTEN, D. \& MOON, J. (2009): "Employee volunteering and social capital: Contributions to corporate social responsibility", British Journal of Management, 20(1), 75-89.

OOSTLANDER, J., et al. (2014): "Leadership and Volunteer Motivation: A Study Using SelfDetermination Theory", Nonprofit and Voluntary Sector Quarterly, 43(5): 869-889.

OPOKU-DAKWA, A. Perceived impacts and employee engagement in corporate volunteering: An interactionist perspective, Dissertation Proposal.

PAJO, K. \& LEE, L. (2011): "Corporate-sponsored volunteering: A work design perspective", Journal of Business Ethics, 99(3), 467-482.

PAVLOVA, M.K. \& SILBEREISEN, R.K. (2014): "Coping with occupational uncertainty and formal volunteering across the life span", Journal of Vocational Behavior, 85(1), 93-105.

PELOZA, J. \& HASSAY, D.N. (2006): "Intra-organizational volunteerism: Good soldiers, good deeds and good politics", Journal of Business Ethics, 64(4), 357-379.

PELOZA, J., HUDSON, S. \& HASSAY, D.N. (2009): "The marketing of employee volunteerism", Journal of Business Ethics, 85(2), 371-386.

PENNER, L.A., DOVIDIO, J.F., PILIAVIN, J.A. \& SCHROEDER, D.A. (2005): "Prosocial behavior: Multilevel perspectives". Annu. Rev. Psychol., 56, 365-392.

PETERSON, D.K. (2004): "Recruitment strategies for encouraging participation in corporate volunteer programs", Journal of Business Ethics, 49(4), 371-386.

PLAGNOL, A.C. \& HUPPERT, F.A. (2010): "Happy to help? Exploring the factors associated with variations in rates of volunteering across Europe", Social Indicators Research, 97(2), 157-176.

PLEWA, C., CONDUIT, J., QUESTER, P.G. \& JOHNSON, C. (2015): "The impact of corporate volunteering on CSR image: A consumer perspective", Journal of Business Ethics, 127(3), 643-659. 
PORTER, M.E. \& KRAMER, M.R. (2002): "The competitive advantage of corporate philanthropy", Harvard business review, 80(12), 56-68.

PRAYUKVONG, W. \& REES, B. (2010): "A Buddhist economic approach to employee volunteer programmes", Journal of Corporate Citizenship, 38, 75-91.

RICKS, J.M. \& PETERS, R.C. (2013): "Motives, timing, and targets of corporate philanthropy: A tripartite classification scheme of charitable giving", Business and Society Review, 118(3), 413-436.

RIOUX, S.M. \& PENNER, L.A. (2001): "The causes of organizational citizenship behavior: a motivational analysis", Journal of applied Psychology, 86(6), 1306.

RODELL, J.B. (2013): "Finding meaning through volunteering: Why do employees volunteer and what does it mean for their jobs?", Academy of Management Journal, 56(5), 1274-1294.

RODRIGO, P. \& ARENAS, D. (2008): "Do employees care about CSR programs? A typology of employees according to their attitudes", Journal of Business Ethics, 83(2), 265-283.

RYAN, R.M. \& DECl, E.L. (2000): "Self-determination theory and the facilitation of intrinsic motivation, social development, and well-being", American psychologist, 55(1), 68.

RYAN, R.M. \& DECl, E.L. (2001): "On happiness and human potentials: A review of research on hedonic and eudaimonic well-being", Annual review of psychology, 52(1), 141-166.

SAJARDO, A.S. \& SERRA, I. (2008): "Avances recientes en la investigación económica sobre el voluntariado: valoración económica del trabajo voluntario, costes de gestión del voluntariado y voluntariado corporativo", CIRIEC-España, Revista de Economía Pública, Social y Cooperativa, 63, 191-225.

SAJARDO, A. \& RIBAS, M.A. (2014): "La inversión social de las empresas: el voluntariado corporativo en España", CIRIEC-España, Revista de Economía Pública, Social y Cooperativa, 80, 161-186.

SEITANIDI, M.M. \& RYAN, A. (2007): "Forms of corporate community involvement: From philanthropy to partnerships. A critical review", International Journal of Nonprofit and Voluntary Sector Marketing (in press) DOI: 10.1002/nvsm.306.

SHEEL, R.C. \& VOHRA, N. (2016): Relationship between perceptions of corporate social responsibility and organizational cynicism: the role of employee volunteering. The International Journal of Human Resource Management, 27(13), 1373-1392.

SMITH, D.H. (1994): "Determinants of voluntary association participation and volunteering: A literature review", Nonprofit and voluntary sector quarterly, 23(3), 243-263.

SNELL, R.S. \& WONG, Y.L. (2007): "Differentiating good soldiers from good actors", Journal of Management Studies, 44(6), 883-909.

STUKAS, A.A., SNYDER, M. \& CLARY, E.G. (1999): "The effects of "mandatory volunteerism" on intentions to volunteer", Psychological Science, 10(1), 59-64. 
THOITS, P.A. \& HEWITT, L.N. (2001): "Volunteer work and well-being", Journal of health and social behavior, 115-131.

TUFFREY, M. (2003): Good Companies, Better Employees, The Corporate Citizenship Company, London.

VAIDYANATHAN, B. (2008): Corporate giving: A literature review, Center for the Study of Religion and Society, University of Notre Dame.

VALENTINE, S. \& FLEISCHMAN, G. (2008): "Ethics programs, perceived corporate social responsibility and job satisfaction", Journal of business ethics, 77(2), 159-172.

VAN DER VOORT, J.M., GLAC, K. \& MEIJS, L.C. (2009): "'Managing” corporate community involvement", Journal of Business Ethics, 90(3), 311-329.

VAN SCHIE, S. et al. (2015): "How the Organizational Context Impacts Volunteers: A Differentiated Perspective on Self-determined Motivation", Voluntas, 26(4), 1570-1590.

VAN WILLIGEN, M. (2000): "Differential benefits of volunteering across the life course", The Journals of Gerontology Series B: Psychological Sciences and Social Sciences, 55(5), 308-318.

VEN VAN DE, B. \& GRAAFLAND, J.J. (2006): "Strategic and moral motivation for corporate social responsibility", JCC, 22, Summer.

WILSON, J. (2000): "Volunteering”, Annual review of sociology, 26, 215-240.

WILSON, J. \& JANOSKI, T. (1995): "The contribution of religion to volunteer work", Sociology of religion, 56(2), 137-152.

WILSON, J. \& MUSICK, M. (1997): "Who cares? Toward an integrated theory of volunteer work", American Sociological Review, 694-713.

WINTERICH, K.P., MITTAL, V. \& AQUINO, K. (2013): "When does recognition increase charitable behavior? Toward a moral identity-based model", Journal of Marketing, 77(3), 121-134.

ZAPPALA, G. (2004): "Corporate citizenship and human resource management: a new tool or a missed opportunity?", Asia Pacific Journal of Human Resources, 42(2), 185-201. 